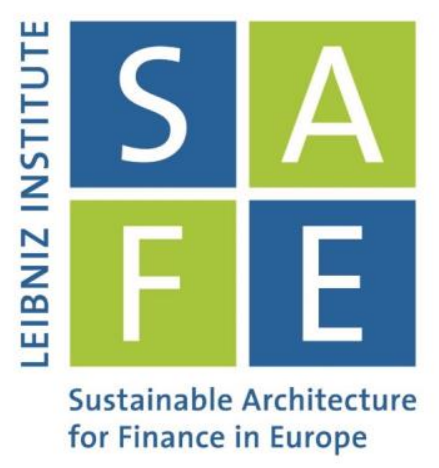

Thomas F. Huertas

\title{
Plug the gap: \\ Make resolution ready for corona
}

SAFE White Paper No. 73 | November 2020

\section{Leibniz Institute for Financial Research SAFE}

Sustainable Architecture for Finance in Europe 


\title{
Plug the gap: \\ Make resolution ready for corona*
}

\author{
Thomas F. Huertas, Goethe University Frankfurt, Center for Financial Studies, Institute for \\ Law and Finance and SAFE
}

November 2020

\begin{abstract}
Banks are not immune from COVID-19. The economic downturn may drive some banks to the point of non-viability (PONV). If so, is the resolution regime in the Euro-area ready to respond? No, for banks may not have the right amount of the right kind of liabilities to make bail-in work. That could lead to a banking crisis. The Euro area can avoid this risk, by arranging now for a recap later. This would plug the gap between what the failing bank has and what it would need to make bail-in work. To do so, banks would pay - possibly via the contributions they make to the Single Resolution Fund - a commitment fee to a European backstop authority for a mandatory, system-wide note issuance facility. This would compel each bank, as it approached or reached the PONV, to issue to the backstop, and the backstop to purchase from the bank, the obligations the failing bank needs in order to make bail-in work. Such obligations would take the form of "senior-most" non-preferred debt, and bail-in would stop with such debt. That would allow the SRB to use the bail-in tool to resolve the failed bank, reopen it and run it under a solvent wind-down strategy. That protects counterparties and customers and ensures the continuity of critical economic functions. It also keeps investors at risk and promotes market discipline. Above all, it preserves financial stability.
\end{abstract}

\section{Introduction}

A banking crisis is the last thing Europe needs. Yet, that is what the Euro-area could get, unless it makes resolution ready for corona.

Banks are not immune from COVID-19. The economic downturn has weakened the financial condition of families and firms, and the situation is likely to get worse, not better, as governments impose new lockdowns. Unemployment is likely to surge, as are corporate bankruptcies. That will put banks under

"SAFE policy papers represent the authors' personal opinions and do not necessarily reflect the views of the Research Center SAFE or its staff. The author is grateful to Charles Goodhart and Patrick Kenadjian for comments. 
pressure, and drive some toward the point of non-viability (PONV). The authorities involved in resolution - supervisors, central banks, finance ministries as well as the resolution authorities themselves - have to be ready to handle the banks that do reach that point.

They are not. The resolution regime is designed to deal with failing banks on a case by case basis. But over the next two to three years banks will not necessarily reach the point of non-viability one at a time or in an orderly queue.

In principle, the resolution regime could handle this. Bail-in allows the authorities to put a failing bank into resolution, recapitalize it, restructure it, and ultimately return it to normal supervision without cost to the taxpayer and without significant disruption to financial markets or the economy at large. This ensures the continuity of critical economic functions, promotes market discipline, and preserves financial stability.

In practice, bail-in works this way if and only if the failing bank has the right amount of the right kind of investor obligations. The right amount is the amount required to absorb losses at the failed bank, recapitalize it, and restore market confidence. The right kind is additional Tier 1 capital, Tier 2 capital and senior non-preferred debt, collectively gone-concern loss-absorbing capacity (GLAC). These obligations to investors are subordinated to operating liabilities to counterparties and customers, such as derivatives and deposits. If bail-in stops at GLAC, it can work.

The trouble is that Euro-area banks do not have enough GLAC. If a bank were to reach the point of non-viability, bail-in becomes more complicated, and might not be possible at all. In that case, the failed bank would enter "liquidation" under the insolvency regime applicable in the Member State in which the failed bank is headquartered. Depending on the Member State, the outcome could range from bail-out to outright liquidation at fire-sale prices. Investors could suffer no loss, be converted into equity, or be wiped out entirely.

In practice, what authorities do shapes what investors expect. Bail-in would confirm that investors are at risk; bail-out, that they might not be, but the Member State providing it could be. If the authorities actually liquidate the failed bank, there will be a "flight to quality" and a run from banks perceived to be weaker. To avoid this, the authorities might exercise forbearance. But zombie banks with nonperforming loans to zombie firms is not a recipe for recovery. In other words, the Euro area may have to play what might be termed "resolution roulette".

The Euro area can avoid this risk, by arranging now for a recap later. This would plug the gap between what the failing bank has and what it would need to make bail-in work. To do so, banks would pay possibly via the contributions they make to the Single Resolution Fund - a commitment fee to a European backstop authority for a mandatory, system-wide note issuance facility. This would compel 
each bank, as it approached or reached the PONV, to issue to the backstop, and the backstop to purchase from the bank, the obligations the failing bank needs in order to make bail-in work. Such obligations would take the form of "senior-most" non-preferred debt, and bail-in would stop with such debt. That would allow the SRB to use the bail-in tool to resolve the failed bank, reopen it and run it under a solvent wind down strategy.

This proposal would create clear and uniform expectations about the outcome of resolution across the Euro area. Investors would be at risk. Indeed, they would be wiped out if the bank fails and the backstop's senior-most non-preferred debt is converted into equity. In contrast, the proposal would protect customers and counterparties. This would ensure the continuity of critical functions, promote market discipline, and strengthen banking union. Above all, it would preserve financial stability.

Now is the time to enact this proposal. It is fine to hope for the best, but folly not to prepare for the worst.

\section{The economic outlook and the outlook for banks in the Euro area}

According to the OECD (2020) global output in 2020 is forecast to fall by $4.5 \%$. Although governments have instituted massive support programmes, it is unlikely that Gross Domestic Product (GDP) will surpass its pre-lockdown levels until 2022 or later, now that the second wave of infections is underway, and an effective vaccination programme remains some ways off (see Figure 1).

Figure 1: A collapse in output followed by a slow recovery

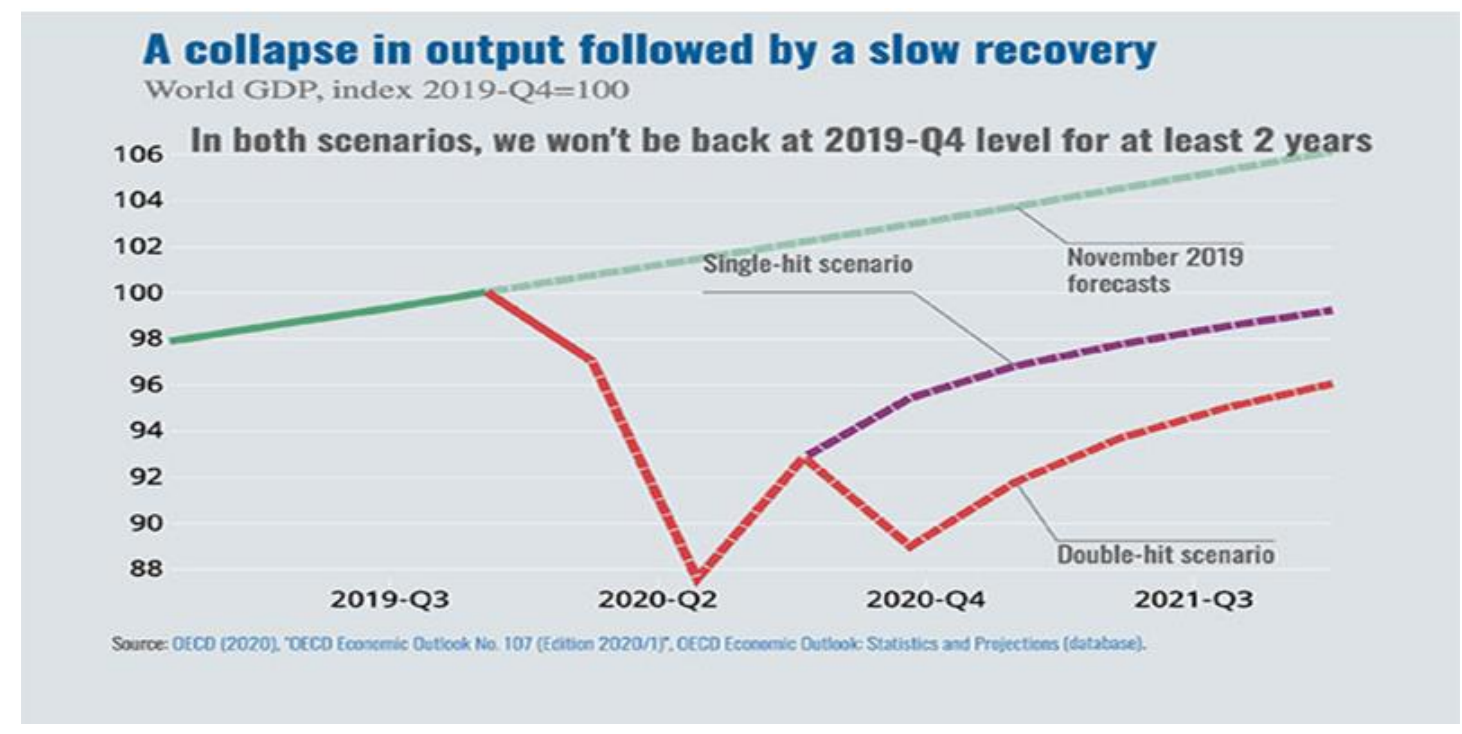

Source: OECD 2020

In the Euro area, the downturn will be worse than the global average. The downturn will be steeper and the rebound, flatter. In 2020 GDP is likely to fall by nearly $8 \%$. Although the economy is likely to grow by $5 \%$ in 2021, this will still leave the economy short of its pre-COVID level. 
This is far greater stress than any previously envisioned in supervisory stress tests, and it is rational to assume that the continuation and possible intensification of economic stress will further weaken the creditworthiness of families and firms.

This will arrest and, in all likelihood, reverse the progress that the Euro area had been making in dealing with non-performing exposures. By the start of the Corona crisis, the ratio of non-performing to all loans and advances at significant banks in the Euro area had fallen to $3.05 \%$ down from $3.68 \%$ a year earlier. In absolute terms, the amount of non-performing loans and advances had fallen to $€ 500$ billion and the amount not covered by provisions to $€ 270$ billion.

The downturn in the economy is likely to drive these numbers back up, particularly at banks with large exposures to heavily indebted sovereigns and/or to sensitive industries, such as tourism and commercial real estate, as well as to highly leveraged and/or lower-rated borrowers (European Central Bank 2020). Total non-performing exposures could rise to $€ 1.4$ trillion (Enria 2020).

Euro area banks have little ability to offset these losses via increased earnings. Negative interest rates depress the return on assets and the flat yield curve limits the reward from maturity transformation. In addition, structural problems persist. Overcapacity depresses margins and limits the ability to make the investments necessary to improve cost-efficiency (Joint ESA Committee 2020, European Central Bank 2020).

Taken together, higher loan losses and low earnings spell weaker capital and the possibility that some banks, perhaps many, will reach the point of non-viability. This would put the resolution regime to the test, particularly if the failing bank(s) were headquartered in heavily indebted Member States. If the resolution regime fails, a banking crisis could result. This would compound the economic downturn (see Figure 2).

Figure 2: A banking crisis would compound the downturn due to COVID

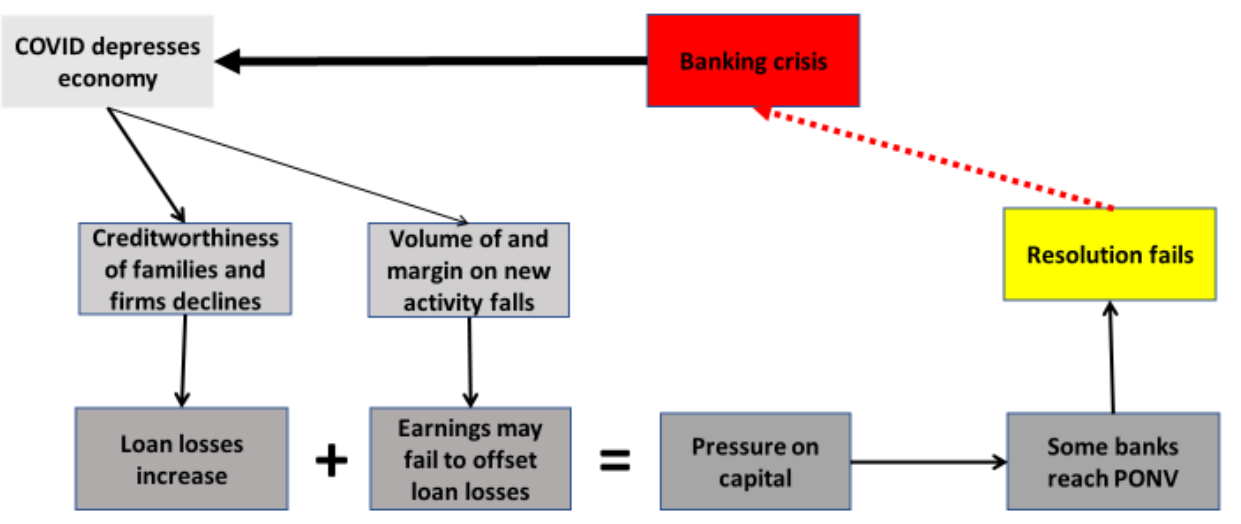

Source: Own representation 


\section{Euro-area banks lack the instruments necessary to make bail-in work effectively}

In principle, bail-in under the Bank Recovery and Resolution Directive (BRRD) would enable the Euro area to avoid such a banking crisis. Bail-in amounts to a pre-pack bankruptcy procedure for banks. Bail-in allows the authorities to put a failing bank into resolution, recapitalize it, restructure it, and ultimately return it to normal supervision without cost to the taxpayer and without significant disruption to financial markets or the economy at large. This ensures the continuity of critical economic functions, enhances financial stability, and promotes market discipline. ${ }^{1}$

Figure 3: Creditor hierarchy under BRRD

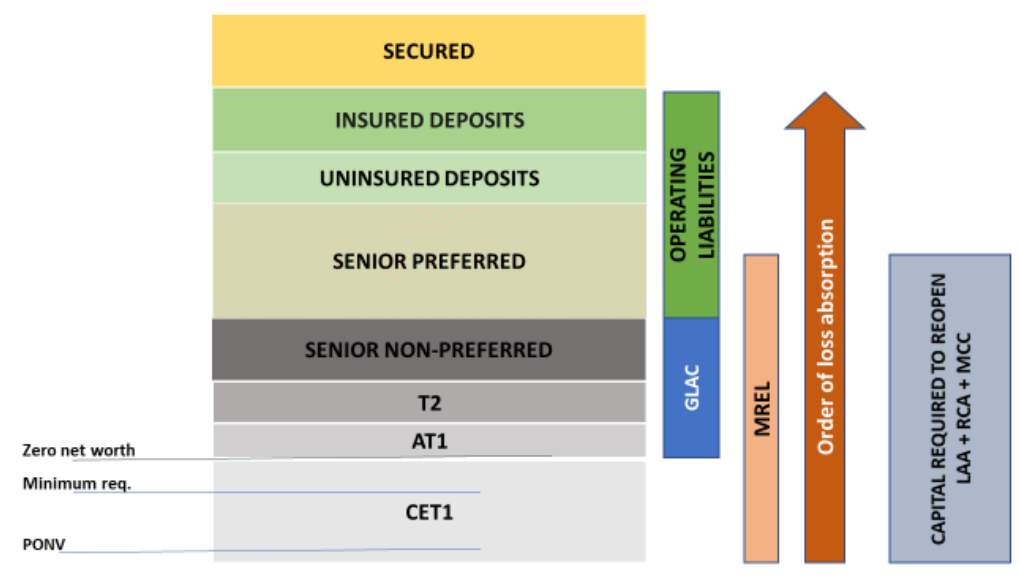

Note: Senior preferred category contains both operating liabilities and MREL. Source: Own representation

\section{Minimum Requirement for Own Funds and Eligible Liabilities (MREL)}

Bail-in depends critically on the failed bank having sufficient loss-absorbing capacity at the point at which it enters resolution to do three things: absorb losses, recapitalize the bank, and restore market confidence in the bank. Accordingly, regulation determines how these requirements should be calculated and how they should be met.

\footnotetext{
${ }^{1}$ Bail-in shifts responsibility from the taxpayer to the investor. This makes banks' funding costs more dependent on the risk the bank takes, rather than the support it could expect to receive, if it were to fail. For evidence that this effect is occurring see Financial Stability Board 2020. For critical assessments of bail-in see Avgoulos \& Goodhart, 2019, Franke, Krahnen, \& von Lüpke, 2014; Binder, 2016. On the calibration of MREL and its impact on market discipline, see (Tröger, 2019).
} 
Figure 4: MREL Uses, requirements and sources

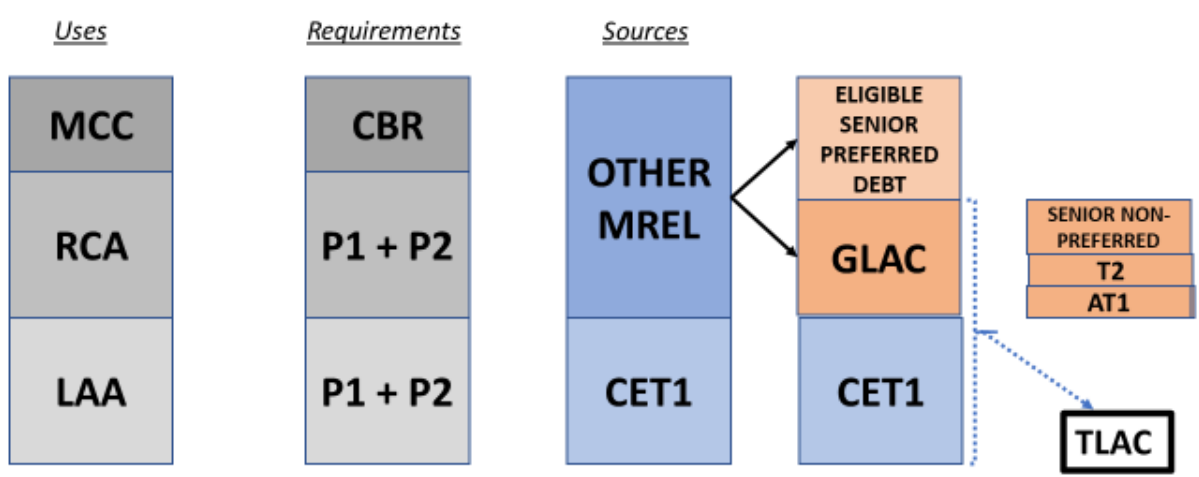

Source: Own representation

The Loss Absorption Amount (LAA) is defined in two ways: ex ante and at the point of resolution. Prior to resolution the LAA is estimated to be equal to higher of the amount of capital sufficient to meet the bank's

- Pillar 1 and Pillar 2 requirements under the risk-weighted approach; and

- Minimum leverage ratio.

This ex ante LAA will be sufficient to absorb actual losses at the point of resolution, if the supervisor (for SIs in the euro area this is the ECB) puts the bank into resolution - as it should - at the point where the bank fails to meet its minimum capital requirement, i.e. at a point where the bank still has a positive net worth. However, this will not be the case, if the authorities exercise forbearance, or massive losses occur suddenly.

At the point of resolution, the resolution authority must estimate the amount of actual losses that the bank-in-resolution will incur. This should be done on the basis of a valuation by an independent valuer, who will provide a provisional estimate at the point of entry into resolution. Note that actual losses may exceed the amount of CET1 capital remaining at the failed bank at the point at which the bank enters resolution, particularly if the authorities have exercised forbearance.

Together, the Recapitalization Amount (RCA) and the Market Confidence Charge (MCC) are the amount of CET1 capital that the bank-in-resolution will require in order to be able to reopen. Ex ante, the RCA is equal to the ex-ante LAA. In other words, the RCA fully replenishes the amount of capital that the bank-in-resolution would need in order to meet its capital requirements. At the point of resolution, the actual RCA may exceed the ex-ante RCA, if the actual LAA exceeds the amount of CET1 capital available. 
The MCC is a supplement to the RCA to enable the bank-in-resolution to obtain market confidence so that it can meet its funding needs without recourse to extraordinary financial support. This is sized at an amount equal to the bank's combined buffer requirement (capital conservation buffer, countercyclical buffer and SIFI surcharge (if applicable)).

To satisfy the MREL requirement banks must keep a combination of CET1 capital and eligible liabilities. Banks must satisfy the LAA component of the requirement with own funds (CET1 capital) and they should have "eligible liabilities" greater than or equal to the RCA and MCC. Broadly speaking, these eligible liabilities include:

- additional Tier 1 capital, Tier 2 capital and qualifying senior non-preferred debt (together gone concern loss absorbing capacity (GLAC)); and

- other eligible liabilities (principally senior preferred debt).

To a first approximation, the sum of own funds and GLAC equals TLAC (total loss absorbing capacity). These elements of MREL rank junior to operating liabilities (see Figure 3), whilst senior preferred debt, the principal component of "other eligible liabilities, ranks pari passu with operating liabilities, such as derivatives, that are also in the senior preferred class.

However, the authorities may only use the bail-in tool if it passes a public interest test. If the tool does not for that particular bank, the authorities either (i) put the failing bank into "liquidation" under the insolvency regime applicable to the bank in the Member State in which it is headquartered, or (ii) exercise forbearance and allow the bank to continue to operate.

To pass the public interest test, use of the bail-in tool has to "avoid a significant adverse effect on the financial system, in particular by preventing contagion, including to market infrastructures, and by maintaining market discipline" (BRRD Art. 31(2)(b)). ${ }^{2}$ This is very unlikely to be the case if bail-in imposes losses on operating liabilities such as derivatives and deposits. If bail-in extends to derivatives, this may put the bank-in-resolution into default at the central counterparties (CCPs) where it is a member (Huertas and Huertas 2020). For a GSIB this would be the case for at least one and possibly even all systemically important CCPs around the world (Huertas 2016), and each of these will have to start its default procedure. That reduces the ability of the bank-in-resolution to retain access to FMIs and carries the possibility that one or more CCPs may themselves require resolution - an outcome that could cause significant market instability (Priem 2018, Singh \& Turing 2018).

\footnotetext{
${ }^{2}$ BRRD Art. 32(5) requires the SRB to demonstrate that the use of the bail-in tool promotes the resolution objectives listed in Art. 31 more effectively than would liquidation under the otherwise applicable national insolvency regime.
} 
If bail-in extends to uninsured deposits, this will interfere with critical economic functions and is likely to further aggravate financial instability. There is also a practical issue of how to bail in uninsured deposits, whilst allowing continued access to insured deposits. In all likelihood, some form of freeze on withdrawals would be required. This would interfere with critical economic functions and aggravate the liquidity challenge facing the bank-in-resolution. Such problems would be all the greater if bail-in were to extend to insured deposits. In sum, if bail-in extends to operating liabilities, it is likely to be counterproductive.

For bail-in to be effective, the failing bank must have at the point of entry into resolution the right kind of obligations to investors in the right amount. The right amount is the amount necessary to absorb losses, recapitalize the bank, and restore market confidence (see Box). The right kind is Additional Tier 1 (AT1) and Tier 2 (T2) capital as well as senior-non preferred debt, collectively goneconcern loss absorbing capacity (GLAC). These are statutorily subordinated to operating liabilities in the creditor hierarchy (see Figure 3).

To ensure that bail-in does not extend to operating liabilities the SRB has set minimum levels (see Table 1) for the elements of MREL that are not own funds (CET1 capital) relative to the bank's total risk exposure amount (TREA), its leverage risk exposure (LRE) and total liabilities and own funds (TLOF). This ensures that there will still be MREL available to recapitalize the failed bank, even if losses fully exhaust the bank's CET1 capital. However, these requirements do not become fully effective until 1 January 2024. Even the intermediate, bank-specific intermediate requirements do not take force until 2022.

Table 1. Minimum subordination requirements for MREL at significant institutions in the euro area

$\begin{array}{llll} & \text { TREA } & \text { LRE } & \text { TLOF } \\ \text { G-SIls } & 18 \%+\text { CBR } & 6.75 \%+\text { CBR } & 8 \% \\ \text { Other SIs } & 13 \%+\text { CBR } & 5 \%+\text { CBR } & 8 \%\end{array}$

Source: Single Resolution Board 2020

But these so-called subordination requirements do not ensure that bail-in will stop short of operating liabilities. There are three reasons why. First, banks may not have the right amount of obligations to investors. Total MREL may be insufficient to absorb losses, recapitalize the bank, and restore market confidence. In fact, there are indications that many euro-area banks may fall short of meeting the MREL subordination requirements. In absolute terms the gap amounts to $€ 100$ billion and is greatest at banks headquartered in France, Italy and Spain, whilst in relative terms the gap is above average at banks headquartered in Belgium, Finland, France, Greece, Ireland and Italy. The danger is most acute 
at the risker non-GSIB banks in Member States with the highest ratios of sovereign debt to GDP (Garcia \& Rocamora, 2019).

Over the next two to three years banks may find it difficult to close such gaps, especially as grandfathered legacy issues mature, Brexit turns English law into third-country law and market conditions tighten in response to the economic downturn. This is especially true for banks that did not have access to capital markets prior to the start of the crisis, as well as banks headquartered in Member States with elevated levels of sovereign indebtedness.

Second, even if the failed bank has the right amount of obligations to investors, it may not have enough of the right kind. As shown in Table 2. banks' outstanding AT1 and T2 capital come nowhere near the MREL subordination requirements summarized in Table 1. It is not clear whether the outstanding senior non-preferred is large enough to do so, as banks are not yet required to report and disclose data on MREL-eligible liabilities according to their rank in the credit hierarchy (European Banking Authority 2020).

Table 2. In June 2020 significant banks may have lacked the kind of obligations to investors needed to make bail-in work

\begin{tabular}{|c|c|c|c|c|c|c|c|c|c|}
\hline & \multirow{2}{*}{$\begin{array}{c}\text { TREA } \\
\text { Amount }\end{array}$} & \multicolumn{2}{|c|}{ Total capital } & \multicolumn{2}{|c|}{ CET1 capital } & \multicolumn{2}{|c|}{ GLAC } & \multicolumn{2}{|c|}{ Gap } \\
\hline & & Amount & Ratio in & Amount & Ratio & Amount & Ratio in & Amount & Ratio in \\
\hline Type of SI by size & $€ B$ & $€ B$ & $\%$ & $€ B$ & in \% & $€ B$ & $\%$ & $€ B$ & $\%$ \\
\hline Total Assets $<€ 30 \mathrm{~B}$ & 135.6 & 29.4 & $21.7 \%$ & 26.2 & $19.3 \%$ & 3.2 & $2.4 \%$ & 14.4 & $10.6 \%$ \\
\hline Total Assets $€ 100 B$ to $€ 200 B$ & 685.4 & 134.6 & $19.6 \%$ & 111.5 & $16.3 \%$ & 23.1 & $3.4 \%$ & 66.0 & $9.6 \%$ \\
\hline Total Assets $>€ 200 B$ & 2629.5 & 502.7 & $19.1 \%$ & 385.1 & $14.7 \%$ & 117.5 & $4.5 \%$ & 224.3 & $8.5 \%$ \\
\hline Source: (European Central B & 2020) & & & & & & & & \\
\hline
\end{tabular}

Note, however, that the BRRD offers the resolution authority the option to turn senior preferred debt into the right kind of obligation to investors. The senior preferred class contains:

- investor obligations statutorily subject to bail-in;

- operating liabilities statutorily exempt from bail-in;

- operating liabilities subject to bail-in but eligible for exclusion from bail-in, if the resolution authority decides in that particular case that the cost of including the liability in bail-in exceeds the benefit. 
If the resolution authority excludes these "optional" operating liabilities from bail-in, investors in senior preferred debt would bear the entire loss attributable to the senior preferred class. ${ }^{3}$ This effectively subordinates senior preferred debt to operating liabilities. On this basis, MREL includes senior preferred debt.

This fact pattern leaves authorities and the economy at large at the mercy of which bank(s) arrive first at the point of non-viability. This dictates the options open to the authorities. The option chosen determines who bears loss, and who bears loss at the first bank to fail may change the expectations and therefore the actions of investors, counterparties and customers at other banks.

If the failing bank has the right amount of the right kind of investor obligations, the authorities can employ the bail-in tool to convert GLAC at the failed bank into CET1 capital. Investors in these instruments suffer losses, but holders of senior preferred debt do not. Nor do derivative counterparties or depositors. This ensures the continuity of critical economic functions, promotes market discipline, and preserves financial stability.

The same results hold, if bail-in extends to the senior preferred class and the exemption of operating liabilities subordinates enough senior preferred debt (when added to GLAC) to absorb losses at the failed bank, recapitalize it and restore market confidence.

Quite different results could arise if the failing bank is put into "liquidation" under the insolvency procedure applicable in the Member State in which the bank is headquartered. The concept of "liquidation" varies across Member States, with results ranging from bail-out to the outright liquidation of assets, possibly at fire-sale prices.

If the resolution takes the form of bail-out, investors might also draw some comfort, at least in fiscally strong Member States. However, this comfort will be scant in Member States that are fiscally weak. Weak governments cannot bail out weak banks without raising concerns about their own creditworthiness. If the resolution of the failing bank takes the form of outright liquidation, this will alarm counterparties and customers as well as investors in other banks. There will be a "flight to quality" and a run from banks perceived to be weaker, especially those headquartered in fiscally weaker Member States. In view of these options, the authorities might elect to kick the can down the

\footnotetext{
${ }^{3}$ Such investors would be eligible for compensation under the "no creditor worse off" principle, part or all of which could be provided by the Single Resolution Fund (if the total amount of liabilities bailed in exceeded $8 \%$ of total liabilities and own funds). But such compensation is (i) limited to the difference between what they would have received under liquidation and what they actually receive, and (ii) subject to a cap on the total amount that the Single Resolution Fund can commit to a single bank.
} 
road by exercising forbearance. But that is a recipe for stagnation: zombie banks with non-performing loans to zombie firms are not a good basis for recovery.

In sum, the resolution authorities potentially face a daunting challenge. As a result of the economic fallout from COVID 19, there may be a wave of bank failures in the euro area. But there is no assurance that authorities can rely on bail-in to maintain financial stability. Ex ante, it remains the case that the authorities could liquidate a failing bank or bail it out. The former could disrupt financial markets and harm the economy at large. The latter could initiate the doom loop from weak banks to weak governments and bring about a euro crisis. In other words, COVID 19 has put the authorities between a rock and a hard place.

\section{A framework for resolution: plug the gap}

There is a way to avoid this trap. It is to plug the gap in GLAC so that bail-in does not touch operating liabilities. This will enable the resolution authorities to employ the bail-in tool with the confidence that it will preserve financial stability and discipline investors.

The route to this result is a system-wide, mandatory, precautionary recapitalization. ${ }^{4}$ However, any injection of public money should take the form of senior non-preferred debt, senior to all other forms of GLAC, but junior to operating labilities. This will permit the authorities to use the bail-in tool if a bank reaches the PONV, and the bail-in tool should become the presumptive path for resolution within the euro area, at least for significant institutions. That would protect counterparties and depositors, but not investors. This would ensure the continuity of critical functions. It would also limit contagion, enhance financial stability, promote market discipline, foster consolidation in the banking system, and break the doom loop from weak banks to weak governments.

Here is how the precautionary recap would work.

The euro area would empower a backstop authority (see Appendix) to offer, and require each bank to subscribe to a mandatory note issuance facility. If a bank reaches the PONV, this facility would compel the bank to issue to the backstop, and the backstop to purchase from the bank, an amount of seniormost non-preferred debt sufficient to ensure that bail-in would stop with such debt. Such debt shall be a separate sub-class in the creditor hierarchy and count toward the bank's MREL requirements. It

\footnotetext{
${ }^{4}$ (Schularick, Steffen, \& Tröger, 2020) also advocate a precautionary recapitalization but recommend that this take the form of common equity. This would serve to prevent failure, but it would also support (and therefore bail out) all other forms of capital including AT1 and T2 capital. Moreover, there is no guarantee that such a programme would succeed in all cases. There still remains the possibility that one or more SIs could reach the PONV. The authorities therefore still need a framework within which they could handle the failure of individual SIs without provoking a banking crisis.
} 
will be senior to all other forms of senior non-preferred debt, but junior to senior preferred debt and operating liabilities. It is therefore the last and final element of MREL to be bailed in (see Figure 4).

Figure 5: Plug the gap: Insertion of senior-most non-preferred removes need for bail-in to extend to operating liabilities

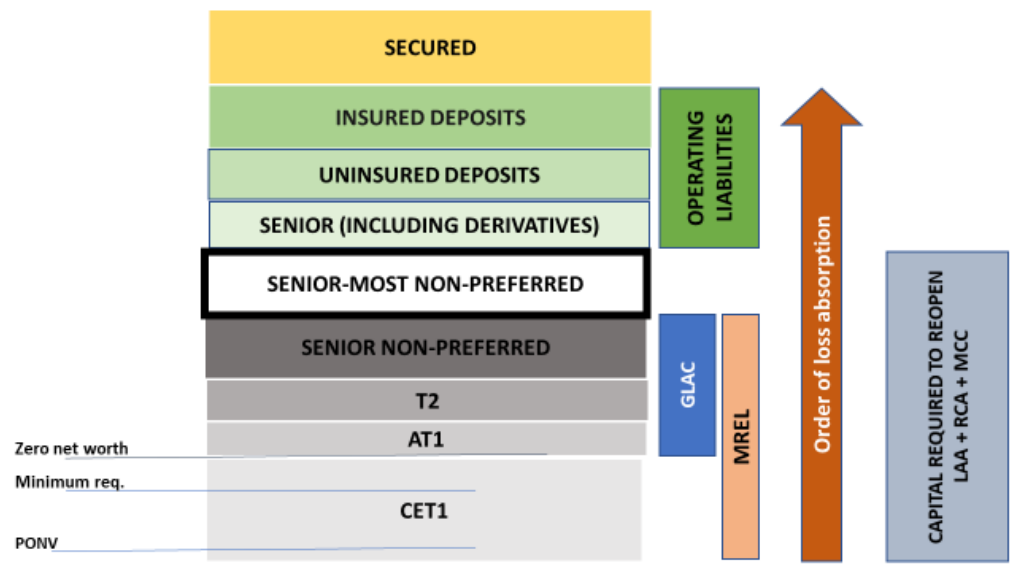

Source: own representation

The term of the facility shall be [four] years. Banks will pay the backstop a commitment fee for this facility, ideally via the contributions that they already make to the Single Resolution Fund (see Appendix).

If the bank enters resolution, the SRB will:

a. Determine the amount of CET1 capital that the bank-in-resolution will require in order to:

i. absorb losses already incurred (the Loss Absorption Amount [LAA]);

ii. recapitalize the bank (the Recapitalization Amount [RCA]); and

iii. restore market confidence in the bank (the Market Confidence Charge [MCC]).

b. Write down or convert any additional Tier 1 and Tier 2 capital into common equity Tier 1 (CET1) capital according to the terms of such instruments.

c. To the extent that the amount of new CET1 required (as per [a]) exceeds the amount created in (b), bail in senior non-preferred debt according to the terms of such instruments.

d. To the extent that the amount of CET1 capital created in (b) and (c) is still not sufficient to meet the requirements under (a), the bank-in-resolution shall issue to the backstop and the backstop shall purchase from the bank-in-resolution, an amount of senior-most non-preferred debt sufficient to enable the bank-in-resolution to meet the requirements under (a), so that it can reopen for business.

If bail-in extends to the class of senior-most non-preferred debt, such debt shall be converted into CET1 capital on the basis that each euro of such debt shall constitute one share of common equity in 
the bank and all previously outstanding shares of CET1 capital (including all shares created as a result of steps (b) and (c) above) shall have a value of $€ 1$. Thus, the provision of public money effectively protects (bails out) operating liabilities. This preserves the continuity of critical functions and promotes financial stability. At the same time, it bails in private investors in all forms of bank capital. They suffer "death by dilution" (Huertas, 2011, p. 136).

Upon reopening, the SRB (as resolution authority) shall execute a solvent wind-down strategy for the failed bank. The SRB may choose to accelerate this wind down via the sale of assets and/or businesses as well as by negotiating the commutation of derivatives and other contracts. This effectively constitutes a solvent run-off or an orderly liquidation of the bank. This will promote the consolidation of the banking sector. ${ }^{5}$

For the duration of the programme, the ECB shall have sole responsibility for extending emergency liquidity assistance (ELA) to significant institutions. If a bank reaches the PONV, the ECB shall support the resolution/run-off process by ensuring that:

- There is no forbearance. The SSB should place the bank into resolution promptly, as soon as the bank is failing or likely to fail, so that the bank still has positive net worth at the point of entry into resolution. This will increase the likelihood that the bank's CET1 capital will be greater than or equal to its LAA at the point of resolution.

- A failing bank enters resolution at the end of the business day. ${ }^{6}$ This may require the ECB to extend ELA to the failing bank during the day prior to its entering resolution at the end of the day to enable the failing bank to make payments to financial market infrastructures and avoid creating Herstatt risk.

- The bank-in-resolution has access to adequate liquidity upon reopening. What the bank-inresolution needs is an access to normal central bank lending facilities against eligible collateral under standard conditions. To facilitate such access arrangements need to be in place to enable the central bank to immediately take charge of the collateral that the bank in resolution would need to pledge to the central bank, including any collateral being returned

\footnotetext{
${ }^{5}$ If two or more failed banks were to come under SRB administration as a result of the conversion of senior-most non-preferred debt into CET1 capital, the SRB shall have the option to merge such banks into a single entity. De facto, this entity could act as the asset management company advocated by Enria (2020).

${ }^{6}$ For bail-in to work, the bank needs to enter resolution at the end of the business day and be current on all of its financial obligations, including those to central banks and to financial market infrastructures, such as clearing houses and central counterparties (CCPs). If the bank is not, the stay on counterparties' right to terminate qualified financial contracts (such as derivatives) will not become effective (BRRD II Rec. 30). Counterparties will begin to close out derivative contracts as well as to sell any collateral pledged by the failed bank, possibly in a firesale that would increase losses at the failed bank and potentially have adverse repercussions for financial markets and the economy at large. See (Huertas and Huertas, 2020).
} 
to the bank when the bank repurchases it at the Monday open from repo lenders who do not wish to roll over their funding.

In light of the contingent nature of and the commitment fee paid for the facility, its provision by a European backstop, the practical extinction of investors' claims upon the bank and the exit via run-off of the bank-in-resolution from the market, such a market-wide mandatory note-issuance facility shall not constitute state aid and therefore need not be subject to state-aid review by the Commission.

Although Member States shall continue to have the right to initiate precautionary recapitalizations under the BRRD, such an application to do so must also include a justification as to why such a step would be consistent with state aid rules and superior, from the perspective of the public interest of the Euro area, to the resolution and solvent wind-down solution available under the "plug the gap" programme outlined here.

\section{Concluding observations}

This proposal would have three additional advantages. First, it would correct shortcomings in the current process by binding the central bank to avoid forbearance, put a failing bank into resolution at the end of the business day and ensure that the bank-in-resolution has access to adequate liquidity upon reopening.

Second, the proposal would facilitate the exit of failing banks. Any bank that comes via resolution under the aegis of the SRB shall pursue a solvent wind-down. The SRB would put it into run-off rather than aim for resurrection. This will facilitate the consolidation of the Euro area banking system.

Third, the proposal would break the doom loop between weak banks and weak governments. Dealing with weak and failing banks would become a Euro area responsibility, in line with supervision. Effectively, the Euro area would assume the responsibility to put a bank into resolution at or before the point at which the bank's net worth reached zero. This protects insured deposits. Indeed, if such responsibility were made permanent, it would open the door to the introduction of a Euro-area deposit guarantee scheme and the completion of Banking union (see Appendix).

Finally, a word on timing: the sooner, the better. 


\section{Appendix:}

The political economy of "plug the gap"

Although the proposal may have economic merit, it also has to pass political muster. Here, three issues are likely to predominate:

\section{Which authority should act as a backstop?}

Ideally, it should be an existing European authority, empowered to invest in the proposed debt instruments (senior-most non-preferred debt) and free from the obligation to impose conditionality on the Member State in which the failing bank is headquartered. The European Stability Mechanism meets the first and the second criterion, but not the third. The Recovery and Resilience Facility may meet the second and the third, but does not meet the first, as the EU has not fully approved it yet.

Does the proposal support the banks?

To date, governments have supported borrowers from banks (firms via guarantee programs and individuals via employment subsidies) rather than banks directly, as they did in the financial crisis. There is still opposition in the many Member States to supporting banks.

Arguably, the proposal supports depositors and counterparties, not banks. Indeed, it amounts to the assurance that banks can be buried (liquidated) in an orderly manner. If the backstop has to inject senior non-preferred debt into a bank-in-resolution, investors in the bank's equity, AT1 and T2 capital shall be wiped out. Customers and counterparties are protected and can continue to transact without interruption.

Provided the supervisor does not exercise forbearance, the backstop will acquire (upon conversion of its senior-most non-preferred debt into CET1 capital) virtually 100\% ownership of a bank with a net worth greater than or equal to the amount of its investment. In other words, it should be at or in the money from day 1 (although exposed to subsequent losses if there is further deterioration in the bank's assets).

If the authorities are exercising forbearance, this defers losses to equity holders, permits investors in maturing GLAC instruments to exit; unsecured creditors to secure their exposures or exit; and management to gamble for resurrection. This increases the likelihood - if the bank were to enter resolution - losses at the failed bank would exceed its remaining CET1 capital as well as the likelihood that bail-in would extend to deposits. The proposal would effectively remove that risk to depositors and act as a warranty that supervisors would put banks into resolution promptly at a point where they still had positive net worth. 
How should banks pay for the commitment fee due to the backstop?

Ideally, banks should pay a commitment fee for the backstop, but do so in a manner that does not adversely affect their creditworthiness. One possible way of doing so is to suspend the build-up in the Single Resolution Fund and use the contributions from banks to fund the commitment fee.

The proposal is certainly consistent with the objective of the Single Resolution Fund "to ensure efficient application of resolution tools and the exercise of the resolution tools conferred to the SRB by the SRM Regulation," as well as the general principle that the financial services industry should be responsible for the cost of resolution (SRF 2020). For the purpose of the $8 \%$ rule, either suspend this for the duration of the facility or reframe it on the basis of the system as a whole for the purpose of this ex ante system-wide facility.

Such a suspension has two advantages. First, it brings to bear funds that would otherwise be impossible to access. Second, it enables EU authorities to promise in advance that people's deposits are safe; that at a time they have to worry about their health, they need not worry about their deposits.

That sounds a lot like a European deposit guarantee. Perhaps that is the political hook to sell the proposal to Member States? 


\section{References}

Avgoulos, E., \& Goodhart, C. (2019). Bank resolution 10 years from the global financial crisis: asystematic reappraisal. School of Political Economy LUISS, 7.

Binder, J.-H. (2016). Resolution: concepts, requirements and tools. In J.-H. Binder, \& D. Singh, Bank Resolution: The European Regime. Oxford: Oxford University Press.

Enria, A. (2020, October 27). Bank asset quality: this time we need to do better. Retrieved from https://www.bankingsupervision.europa.eu/press/interviews/date/2020/html/ssm.in201027 31fda 4bb8e.en.html

European Banking Authority. (2020, August 3). Final Report. Draft implementing technical standards on disclosure and reporting of MREL and TLAC (EBA/ITS/2020/06). Retrieved from https://eba.europa.eu/sites/default/documents/files/document_library/Publications/Consultations/ 2020/CP\%20on\%20ITS\%20on\%20disclosure\%20and\%20reporting\%20of\%20MREL\%20and\%20TLAC/ 898092/Final\%20report\%20on\%20draft\%20ITS\%20on\%20disclosure\%20and\%20reporting\%20

European Central Bank. (2020, May 30). Financial Stability Review. Retrieved from https://www.ecb.europa.eu/pub/financial-stability/fsr/html/ecb.fsr202005 1b75555f66.en.html

European Commission. (2012). Impact Assessment BRRD.

European Stability Mechanism. (2020). ESM Treaty. Retrieved from https://www.esm.europa.eu/sites/default/files/20150203_-_esm_treaty_-_en.pdf

Financial Stability Board. (2020, June 28). Evaluation of the effects of too-big-to-fail reforms. Retrieved from https://www.fsb.org/wp-content/uploads/P280620-1.pdf

Franke, G., Krahnen, J., \& von Lüpke, T. (2014). Effective resolution of banks: Problems and solutions.

Garcia, J., \& Rocamora, M. (2019, October). MREL in European banks: Requirement and shortfall under BRRD II. Retrieved from BBVA Research: https://www.bbvaresearch.com/en/publicaciones/mrel-ineuropean-banks-requirement-and-shortfall-under-brrd-ii/

Hellwig, M. F. (2018). Valuation reports in the context of banking resolution: What are the Challenges. Retrieved from https://www.europarl.europa.eu/RegData/etudes/IDAN/2018/624417/IPOL_IDA\%282018\%2962441 7_EN.pdf

Huertas, T. F. (2011). Crisis: Cause, Containment and Cure (2nd ed.). London: Palgrave Macmillan.

Huertas, T. F. (2016). How to deal with the Resolution of Financial Market Infrastructures.

Huertas, T. F. (2019, September 2). Completing Banking Union. Retrieved from SAFE White Paper 63: https://safe-

frankfurt.de/fileadmin/user_upload/editor_common/Policy_Center/SAFE_White_Paper_63.pdf 
Huertas, T. F., \& Huertas, M. D. (2020, April). Necessary but not Sufficient: Stay Upon Resolution via Bail-In. Butterwrths Journal of International Banking and Financial Law, 235-238.

Joint Committee of the European Supervisory Authorities. (2020, September). Report of the Risks and Vulnerabilities in the European Financial System. Retrieved from https://eba.europa.eu/sites/default/documents/files/document_library/Risk\%20Analysis\%20and\%2 OData/Risk\%20Assessment\%20Reports/2020/932012/JC\%202020\%2067\%20Autumn\%202020\%20Re port\%20on\%20Risks\%20and\%20Vulnerabilities.pdf

OECD. (2020). OECD Economic Outlook, Interim Report September 2020. Retrieved from https://doi.org/10.1787/34ffc900-en.

Priem, R. (2018). CCP recovery and resolution: preventing a financial catastrophe. Journal of Financial Regulation and Compliance.

Schularick, M., Steffen, S., \& Tröger, T. H. (2020, June). Bank capital and the European recovery from the COVID-19 crisis. Retrieved from SAFE White Paper 69: https://safefrankfurt.de/fileadmin/user_upload/editor_common/Policy_Center/SAFE_White_Paper_69.pdf

Singh, M., \& Turing, D. (2018). Central Counterparties Resolution-An Unresolved Problem. (International Monetary Fund.

Single Resolution Board. (2019, February 19). Framework for Valuation. Retrieved from https://srb.europa.eu/sites/srbsite/files/framework_for_valuation_feb_2019_web_0.pdf

Single Resolution Board. (2020). Minimum Requirement for Own Funds and Eligible Liabilities (MREL): SRB Policy under the Banking Package. Retrieved from https://srb.europa.eu/sites/srbsite/files/srb_mrel_policy_2020.pdf

Single Resolution Board. (2020). The Single Resolution Fund. Retrieved from https://srb.europa.eu/sites/srbsite/files_def_srb_fund-web.pdf

Tröger, T. H. (2019). ,Why MREL won't help much: minimum requirements for bail-in capital as an insufficient remedy for defunct private sector involvement under the European bank resolution framework. Journal of Banking Regulation, 1. 